\title{
Effect of EDTA on the bioavailability to rats of fortification iron used in Egyptian balady bread*
}

\author{
BY PAUL WHITTAKER AND JOHN E. VANDERVEEN \\ Food and Drug Administration, Division of Nutrition, $200 \mathrm{C}$ Street, SW (HFF-268), \\ Washington DC 20204, USA
}

(Received 30 August 1989 - Accepted 6 December 1989)

\begin{abstract}
The effectiveness of EDTA compounds on iron fortificants for potential use in Egyptian balady bread was tested in sixty Sprague-Dawley weanling male rats by the haemoglobin regeneration efficiency (HRE) method. To confirm HRE-derived findings, eight groups of ten animals were repleted with a modified American Institute of Nutrition (1977; AIN) 76A diet, fortified with ferric phosphate, electrolytic Fe, carbonyl Fe or ferrous sulphate, with and without ascorbic acid. Results without ascorbic acid were comparable to findings of a human study by Forbes $e t$ al. (1989). Bioavailability of EDTA-enhanced fortificants, $\mathrm{FeSO}_{4}+\mathrm{Na}_{2}$ EDTA and $\mathrm{NaFe}$ (III)EDTA, was compared with that of $\mathrm{FeSO}_{4}$ in six groups of ten animals repleted with a ground Egyptian bread meal or a casein-based AIN diet fortified with one of the three compounds. Addition of either EDTA compound significantly increased bioavailability of $\mathrm{Fe}$ in Egyptian balady bread. When present in the less inhibitory casein meal, however, $\mathrm{FeSO}_{4}+\mathrm{Na}_{2} \mathrm{EDTA}$ fortification was significantly less effective than $\mathrm{NaFe}$ (III)EDTA or the reference $\mathrm{FeSO}_{4}$. Results indicate that $\mathrm{NaFe}$ (III)EDTA may be the fortificant of choice in a mixed diet. Further study of EDTAenhanced $F e$ fortificants is needed.
\end{abstract}

Iron: EDTA: Bioavailability of iron: Bread: Rat

Iron fortification of wheat flour or other cereals is currently being used in many countries as a nutritional strategy. The universal consumption of bread and the usual lower bran content of wheat flour compared with that of other cereals makes flour the food vehicle of choice for Fe fortification throughout the world (Cook \& Reusser, 1983), although Fe absorption from flat breads common to the Middle East is suspected to be less than that from American or European breads. The prevalence of Fe deficiency in Egypt makes fortification of wheat flour desirable, as the average annual consumption of wheat flour, i.e. $180 \mathrm{~kg} /$ person, provides nearly $50 \%$ of the average daily intake of energy and protein. In Egypt, the addition of $\mathrm{Fe}$ to flat breads is a practical fortification strategy, as this food vehicle is available to even the lowest economic groups.

We therefore compared the bioavailability of two EDTA-enhanced Fe compounds, $\mathrm{Na}_{2}$ EDTA with ferrous sulphate and $\mathrm{NaFe}$ (III)EDTA, with that of a reference, $\mathrm{FeSO}_{4}$, with the goal of determining the most bioavailable form of Fe fortification to use in local balady bread, the more popular of two widely consumed flat breads. The identical fortification compounds were also tested using the American Institute of Nutrition (1977; AIN) diet as a food vehicle for comparison with the balady bread. The study was performed as a collateral part of a project sponsored by the Agency for International Development, US Department of Agriculture, University of Kansas Medical Center, and US Food and Drug Administration to improve the general Fe status of the Egyptian population. This project involves Fe fortification, flour milling, and bread production in

* The study was presented in part at the 73rd Annual Meeting of the Federation of American Societies for Experimental Biology, New Orleans, LA, 1989. 
the El-Fayum and Ismailia governorates of Egypt. Previous studies have shown that the inhibitory bran often found in the highly extracted flour $(82 \%)$ used in the balady flat bread of Egypt reduces bioavailability of traditional Fe sources (Widdowson \& McCance, 1942 ; Cook et al. 1973; Bjorn-Rasmussen, 1974; Simpson et al. 1981; El Guindi et al. 1988).

EDTA as an Fe chelate is known to facilitate Fe absorption, in addition to stabilizing the element. A recent study indicated that human subjects fed on balady bread fortified with both $\mathrm{FeSO}_{4}$ and $\mathrm{Na}_{2}$ EDTA exhibited significantly improved Fe absorption (Cook et al. 1973; El Guindi et al. 1988). Animal studies were therefore performed to define further the enhancing potential of EDTA.

Bioavailabilities of several Fe sources with and without ascorbic acid when given with a modified AIN 76A diet were first measured by the haemoglobin regeneration efficiency (HRE) method for comparison with a recent human study (Forbes et al. 1989) and to evaluate the AIN 76A diet with and without ascorbic acid. The second study compared the two EDTA-enhanced compounds, NaFeEDTA and $\mathrm{FeSO}_{4}+\mathrm{Na}_{2}$ EDTA, with the reference $\mathrm{FeSO}_{4}$ by using the HRE method in a rat model. Fe-EDTA compounds were given with an inhibitory meal (ground Egyptian balady bread) and with a less inhibitory meal (the casein-based AIN 76A diet) as a basis for comparison.

\section{MATERIALS AND METHODS}

Fe bioavailability was determined in 140 Sprague-Dawley weanling male rats (Blue Spruce Farms, Inc., Altamont, NY) by HRE (Forbes et al. 1989; Mahoney \& Hendricks, 1982). Animals were individually housed in stainless steel cages and maintained in a temperatureand light-controlled environment. The procedure was divided into two studies. The first study evaluated the bioavailability of four Fe-fortification compounds with and without ascorbic acid. Eight groups each of ten animals were used to determine the bioavailability of $\mathrm{FeSO}_{4} .7 \mathrm{H}_{2} \mathrm{O}$ (Mallinckrodt Inc., Paris, KY), electrolytic Fe with an average particle size of $20 \mu \mathrm{m}$ and $\mathrm{FePO}_{4} \cdot 2 \mathrm{H}_{2} \mathrm{O}$ (New England Nuclear, Boston, MA), both prepared for a previous study (Forbes et al. 1989), and carbonyl Fe (Ferronyl Fe; GAF Chemicals Corporation, Wayne, $\mathrm{NJ}$ ) with an average particle size of $46 \mu \mathrm{m}$, with and without ascorbic acid. The second study determined the bioavailability of three Fe-fortification compounds, NaFeEDTA (Hamp-ene NaFe Purified Grade; W. R. Grace \& Co., Nashua, $\mathrm{NH}$ ), $\mathrm{Na}_{2}$ EDTA. $2 \mathrm{H}_{2} \mathrm{O}$ (Hamp-ene $\mathrm{Na}_{2}$ Pure; W. R. Grace \& Co.) and $\mathrm{FeSO}_{4} \cdot 7 \mathrm{H}_{2} \mathrm{O}$, with the modified AIN 76A diet and air-dried, ground Egyptian balady bread in combination with the AIN 76A vitamin and mineral mix minus ferric citrate by using six groups of ten animals, a total of sixty animals.

Anaemia was induced in all animals by phlebotomy from the orbital venus plexus (Tim, 1979) and by ad lib. feeding with a low-Fe diet ( $10 \mu \mathrm{g} \mathrm{Fe} / \mathrm{g}$ diet $)$ comprising a modified AIN semi-purified rat diet without ferric citrate and containing $(\mathrm{g} / \mathrm{kg}$ diet $)$ : casein $200 \cdot 0$, DLmethionine 3.0, maize starch $150 \cdot 0$, glucose 500.0, fibre (Celufil) $50 \cdot 0$, maize oil $50 \cdot 0$, AIN 76 mineral mix (without ferric citrate) 35.0, AIN 76A vitamin mix 10.0 (AIN, 1980) and choline bitartrate $2 \cdot 0$ (US Biochemical Co., Cleveland, $\mathrm{OH}$ ). Deionized, distilled water was also available $a d$ lib. during both the depletion and repletion periods. After $7 \mathrm{~d}$ depletion on the low-Fe diet, animals were weighed, packed cell volume was determined, and haemoglobin concentration was measured in duplicate from a specimen of fresh blood by the cyanmethaemoglobin method (Crosby \& Munn, 1954). The animals were then randomized into eight groups (study 1 ) or six groups (study 2 ) of approximately equal mean body-weight and haemoglobin concentration.

Eight diets containing $35 \mathrm{mg}$ fortification $\mathrm{Fe} / \mathrm{kg}$ diet were prepared for the repletion period for study 1 . In study 2 , six repletion diets containing $30 \mathrm{mg} \mathrm{Fe} / \mathrm{kg}$ were prepared. 
Table 1. Diets given to rats during the $10 \mathrm{~d}$ repletion period in studies 1 and 2

\begin{tabular}{|c|c|c|c|c|}
\hline Study & Group & Iron compared* & Enhancer used $\dagger$ & Diet \\
\hline \multirow[t]{8}{*}{1} & 1 & $\mathrm{FeSO}_{4} \cdot 7 \mathrm{H}_{2} \mathrm{O}$ & - & AIN \\
\hline & 2 & Electrolytic Fe & - & AIN \\
\hline & 3 & $\mathrm{FePO}_{4} \cdot 2 \mathrm{H}_{2} \mathrm{O}$ & - & AIN \\
\hline & 4 & Carbonyl Fe & $\ldots$ & AIN \\
\hline & 5 & $\mathrm{FeSO}_{4} .7 \mathrm{H}_{2} \mathrm{O}$ & Ascorbic acid & AIN \\
\hline & 6 & Electrolytic Fe & Ascorbic acid & AIN \\
\hline & 7 & $\mathrm{FePO}_{4} \cdot 2 \mathrm{H}_{2} \mathrm{O}$ & Ascorbic acid & AIN \\
\hline & 8 & Carbonyl Fe & Ascorbic acid & AIN \\
\hline \multirow[t]{6}{*}{2} & 1 & $\mathrm{FeSO}_{4} \cdot 7 \mathrm{H}_{2} \mathrm{O}$ & - & AIN \\
\hline & 2 & $\mathrm{FeSO}_{4} \cdot 7 \mathrm{H}_{2} \mathrm{O}$ & $\mathrm{Na}_{2}$ EDTA & AIN \\
\hline & 3 & NaFeEDTA & - & AIN \\
\hline & 4 & $\mathrm{FeSO}_{4} \cdot 7 \mathrm{H}_{2} \mathrm{O}$ & - & Egyptian bread $\downarrow$ \\
\hline & 5 & $\mathrm{FeSO}_{4} \cdot 7 \mathrm{H}_{2} \mathrm{O}$ & $\mathrm{Na}_{2} \mathrm{EDTA}$ & Egyptian bread \\
\hline & 6 & NaFeEDTÁ & $n^{2}+$ & Egyptian bread \\
\hline
\end{tabular}

AIN, Modified American Institute of Nutrition (1977) 76A diet.

* Study 1 used $35 \mathrm{mg} \mathrm{Fe}$ and study 2 used $30 \mathrm{mg} \mathrm{Fe} / \mathrm{kg}$ diet for fortification.

$\uparrow$ Ascorbic acid $\left(985 \mathrm{mg} / \mathrm{kg}\right.$ diet) or $\mathrm{Na}_{2}$ EDTA (1: I molar ratio).

¥ Balady bread; for details, see p. 588 .

AIN 76 mineral mix (without ferric citrate) was used in the same proportion as in the AIN diet $(30 \mathrm{~g} / \mathrm{kg}$ diet $)$ and the AIN $76 \mathrm{~A}$ vitamin mix $(10.0 \mathrm{~g} / \mathrm{kg})$ and choline bitartrate in the amount of $2.0 \mathrm{~g} / \mathrm{kg}$ for the three experimental groups that received the Egyptian bread. Bread made with Fe-fortified flour was the Fe source for the sixth group. Each diet given during the $10 \mathrm{~d}$ repletion period was supplemented with one of the Fe compounds listed in Table 1. Fe concentrations were verified by atomic absorption spectroscopy (Boline \& Schrenk, 1977).

Fresh food was weighed daily for each animal. At the conclusion of the repletion period, body-weight, haemoglobin concentration, packed cell volume ratio, and total food intake were determined. Haemoglobin-Fe (Hb-Fe, mg) was determined (Forbes et al. 1989; Whittaker et al. 1984) as follows:

$$
\mathrm{Hb}-\mathrm{Fe}(\mathrm{mg})=\text { body-wt }(\mathrm{kg}) \times \frac{0.075 \text { litres blood }}{\text { body-wt(kg)}} \times \frac{\mathrm{Hb}(\mathrm{g})}{\mathrm{blood}(\mathrm{l})} \times \frac{3.35 \mathrm{mg} \mathrm{Fe}}{\mathrm{Hb}(\mathrm{g})} .
$$

HRE values were calculated for each animal by the following equation:

$$
\mathrm{HRE}=\frac{\mathrm{mg} \mathrm{Hb}-\mathrm{Fe}(\text { final })-\mathrm{mg} \mathrm{Hb}-\mathrm{Fe}(\text { initial })}{\mathrm{mg} \mathrm{Fe} \text { consumed }} .
$$

The relative biological value (RBV) was determined by dividing the individual HRE values of the test $\mathrm{Fe}$ source by the mean $\mathrm{HRE}$ of $\mathrm{FeSO}_{4}$. After animals were killed, livers were excised and frozen for non-haem-Fe determination at a later time. Non-haem-Fe was determined in livers by a slightly modified bathophenanthroline method (Torrance \& Bothwell, 1968) and expressed as both $\mu \mathrm{g} \mathrm{Fe} / \mathrm{g}$ liver and total $\mu \mathrm{g} \mathrm{Fe} /$ liver. A 2 g portion of each previously blotted liver was weighed. Distilled, deionized water was added to bring the volume to $15 \mathrm{ml}$ in a disposable $50 \mathrm{ml}$ polypropylene centrifuge tube, and the mixture was homogenized for $30 \mathrm{~s}$ using a Polytron. A $3 \mathrm{ml}$ portion was transferred to another $50 \mathrm{ml}$ centrifuge tube, and $10 \mathrm{ml}$ acid reagent were added (6 $\mathrm{M}$-hydrochloric acid-1.2 $\mathrm{M}$ trichloroacetic acid) $(1: 1, \mathrm{v} / \mathrm{v})$ and mixed well. The tubes were then placed in an oven at $65^{\circ}$ for $20 \mathrm{~h}$. Tubes were cooled and centrifuged at $1500 \mathrm{~g}$ for $20 \mathrm{~min}$. Duplicate portions 


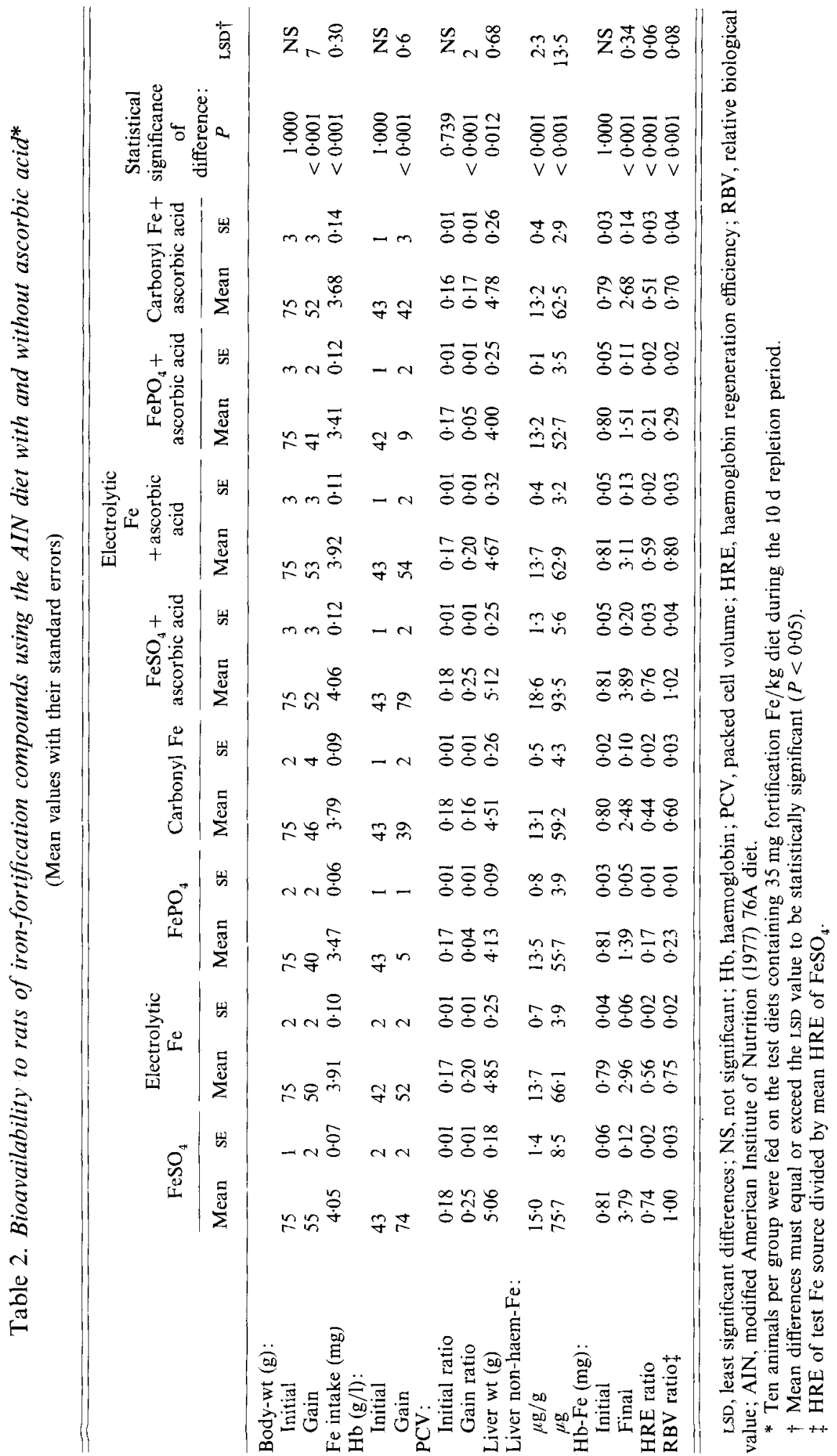


of $0.2 \mathrm{ml}$ supernatant fraction were pipetted into small plastic tubes, $1.8 \mathrm{ml}$ freshly prepared colour reagent was added and mixed, and the mixture was incubated for $10 \mathrm{~min}$ at room temperature. Bathophenanthroline colour reagent (which was kept in the dark) was first prepared by dissolving $62.5 \mathrm{mg}$ bathophenanthroline sulphonate and $0.25 \mathrm{ml}$ thioglycolic acid in distilled, deionized water, and diluting to $25 \mathrm{ml}$. The colour reagent was a solution of bathophenanthroline reagent - saturated sodium acetate $(4.5 \mathrm{M})$-distilled, deionized water $(1: 20: 20$, by vol.). A new reagent was prepared every 2 weeks. Absorbance was determined by spectrophotometry at $535 \mathrm{~nm}$; Fe concentration $(\mu \mathrm{g} \mathrm{Fe} / \mathrm{ml})$ was determined by reference to a standard curve.

Values were analysed by one-way analysis of variance. Means were compared by the least significant difference method when statistically significant $(P<0.05)$ (Snedecor \& Cochran, 1967).

\section{RESULTS}

In Study 1, the RBV of the iron fortificants (electrolytic $\mathrm{Fe}, \mathrm{FePO}_{4}$, and carbonyl $\mathrm{Fe}$ ) were compared with the reference $\mathrm{FeSO}_{4}$ with and without ascorbic acid. With only one exception, all indicators showed that the addition of ascorbic acid produced no significant enhancement of $\mathrm{Fe}$ absorption. Liver non-haem $\mathrm{Fe}$ was significantly higher $(P<0.001)$ only in the reference group receiving ascorbic acid compared with the group not receiving ascorbic acid. Average RBV ratio values without ascorbic acid were 1.00, 0.75, 0.23 and 0.60 for $\mathrm{FeSO}_{4}$, electrolytic $\mathrm{Fe}, \mathrm{FePO}_{4}$ and carbonyl $\mathrm{Fe}$ respectively, compared with 1.02, $0.80,0.29$ and 0.70 with the addition of approximately $1 \mathrm{mg}$ ascorbic acid/g diet (Table 2).

In Table 3, $\mathrm{FeSO}_{4}+\mathrm{Na}_{2}$ EDTA and NaFeEDTA are compared with the reference $\mathrm{FeSO}_{4}$ in the modified AIN 76A diet. Average HRE ratios for meals that used fortified AIN 76A diet were $0.73,0.63$ and 0.94 for $\mathrm{FeSO}_{4}, \mathrm{FeSO}_{4}+\mathrm{Na}_{2}$ EDTA and $\mathrm{NaFeEDTA}$ respectively; the corresponding RBV ratios were $1 \cdot 00,0.86$ and $1 \cdot 28$. The addition of $\mathrm{FeSO}_{4}+\mathrm{Na}_{2} \mathrm{EDTA}$ to the modified AIN diet significantly reduced $(P<0.001)$ the resulting HRE and RBV ratios. The group receiving $\mathrm{NaFeEDTA}$ had a significantly higher haemoglobin gain than the other two groups $\left(\mathrm{FeSO}_{4}\right.$ and $\mathrm{FeSO}_{4}+\mathrm{Na}_{2}$ EDTA), but there were no significant differences in the liver non-haem-Fe values (Table 3 ).

Average HRE ratios using fortified Egyptian bread were $0.51,0.83$ and 0.86 for $\mathrm{FeSO}_{4}$, $\mathrm{FeSO}_{4}+\mathrm{Na}_{2}$ EDTA and $\mathrm{NaFeEDTA}$ respectively; corresponding $\mathrm{RBV}$ ratios were 1.00 , 1.64 and 1.70 (Table 4). The HRE and RBV ratios were significantly higher $(P<0.001)$ for both $\mathrm{NaFeEDTA}$ and $\mathrm{FeSO}_{4}+\mathrm{Na}_{2}$ EDTA in the balady bread than for the fortificant $\mathrm{FeSO}_{4}$. The average haemoglobin gain for the $\mathrm{FeSO}_{4}$ group was $54 \mathrm{~g} / 1$, compared with $87 \mathrm{~g} / 1$ for both the $\mathrm{FeSO}_{4}+\mathrm{Na}_{2}$ EDTA and NaFeEDTA groups, which was also significantly higher.

\section{DISCUSSION}

Fe deficiency is prevalent in Third World countries in which the dietary staples tend to be high in cereal and vegetables but poor in animal protein. Inhibitory factors commonly present in a diet high in vegetable content and low in haem-Fe cause a high incidence of Fe-deficiency anaemia in these developing countries.

Two possible interventions are supplementation and fortification. Difficulty of obtaining reliable distribution, compliance and correct dosage of supplementary Fe generally makes fortification of a universally available food staple the more practical strategy. Fortification is generally inexpensive to initiate and maintain and is the most effective means of reaching all segments of a population. Fortification also provides the most reliable method for achieving long-term enhancement of Fe status. For this reason, balady bread, a widely consumed and universally available flat bread, was chosen as the food vehicle, although it 
Table 3. Comparison of NaFeEDTA and ferrous sulphate $+N a_{2} E D T A$ in the AIN diet with $\mathrm{FeSO}_{4}$ in rats*

(Mean values with their standard errors)

\begin{tabular}{|c|c|c|c|c|c|c|c|c|}
\hline & \multicolumn{2}{|c|}{$\mathrm{FeSO}_{4}$} & \multicolumn{2}{|c|}{$\mathrm{FeSO}_{4}+\mathrm{Na}_{2} \mathrm{EDTA}$} & \multicolumn{2}{|c|}{ NaFeEDTA } & \multirow{2}{*}{$\begin{array}{c}\text { Statistical } \\
\text { significance } \\
\text { of } \\
\text { difference: } \\
P\end{array}$} & \multirow[b]{2}{*}{$\operatorname{LSD}^{\dagger}$} \\
\hline & Mean & $\mathrm{SE}$ & Mean & SE & Mean & $\mathrm{SE}$ & & \\
\hline \multicolumn{9}{|l|}{ Body-wt (g): } \\
\hline Initial & 79 & 5 & 79 & 3 & 80 & 3 & 0.989 & NS \\
\hline Gain & 52 & 2 & 50 & 1 & 53 & 1 & 0.496 & NS \\
\hline Fe intake (mg) & 3.52 & $0 \cdot 11$ & $3 \cdot 65$ & 0.08 & 3.62 & $0 \cdot 11$ & 0.654 & NS \\
\hline \multicolumn{9}{|l|}{$\mathrm{Hb}(\mathrm{g} / \mathrm{l})$ : } \\
\hline Initial & 45 & 3 & 45 & 3 & 45 & 3 & 0.999 & NS \\
\hline Gain & 60 & 2 & 53 & 2 & 84 & 4 & $<0.001$ & $0 \cdot 9$ \\
\hline \multicolumn{9}{|l|}{ PCV: } \\
\hline Initial ratio & $0 \cdot 19$ & 0.01 & $0 \cdot 18$ & 0.01 & $0 \cdot 19$ & 0.01 & 0.948 & NS \\
\hline Gain ratio & 0.21 & 0.01 & 0.20 & 0.01 & $0 \cdot 19$ & 0.01 & 0.363 & NS \\
\hline Liver wt (g) & $5 \cdot 62$ & 0.24 & $5 \cdot 18$ & $0 \cdot 17$ & $5 \cdot 52$ & $0 \cdot 24$ & 0.337 & NS \\
\hline \multicolumn{9}{|c|}{ Liver non-haem-Fe: } \\
\hline$\mu \mathrm{g} / \mathrm{g}$ & $21 \cdot 4$ & $0 \cdot 8$ & $20 \cdot 3$ & $0 \cdot 8$ & $20 \cdot 1$ & $0 \cdot 8$ & 0.457 & NS \\
\hline$\mu \mathrm{g}$ & 121 & 7 & 105 & 5 & 111 & 7 & 0.253 & NS \\
\hline \multicolumn{9}{|l|}{$\mathrm{Hb}-\mathrm{Fe}(\mathrm{mg})$ : } \\
\hline Initial & 0.92 & $0 \cdot 10$ & $0 \cdot 91$ & 0.08 & 0.92 & 0.08 & 0.997 & NS \\
\hline Final & 3.50 & 0.23 & $3 \cdot 20$ & $0 \cdot 14$ & $4 \cdot 30$ & 0.18 & $<0.001$ & 0.54 \\
\hline HRE ratio & 0.73 & 0.03 & 0.63 & $0-02$ & $0 \cdot 94$ & 0.03 & $<0.001$ & $0 \cdot 09$ \\
\hline RBV ratio $\neq$ & 1.00 & 0.03 & 0.86 & 0.03 & $1 \cdot 28$ & 0.05 & $<0.001$ & $0 \cdot 12$ \\
\hline
\end{tabular}

LSD, least significant difference; NS, not significant; Hb, haemoglobin; PCV, packed cell volume; HRE, haemoglobin regeneration efficiency; RBV, relative biological value; AIN, modified American Institute of Nutrition (1977) 76A diet.

* Ten animals per group were fed on the test diets containing $30 \mathrm{mg}$ fortification $\mathrm{Fe} / \mathrm{kg}$ diet during the $10 \mathrm{~d}$ repletion period.

$\dagger$ Mean differences must equal or exceed LSD values to be statistically significant $(P<0.05)$.

$\ddagger$ HRE of test Fe source divided by mean HRE of $\mathrm{FeSO}_{4}$.

is prepared with flour of unusually high extraction ( $82 \%$ ) with associated high bran content and is also baked at very high temperatures (approximately $500^{\circ}$ ) (El Guindi et al. 1988). As both factors may inhibit Fe bioavailability, the addition of EDTA as an Fe-enhancing compound was recommended, and was used in the present study. El Guindi et al. (1988), in a human absorption study using balady bread as the food vehicle, found that $\mathrm{FeSO}_{4}+\mathrm{Na}_{2}$ EDTA added in a 1:1 molar ratio increased $\mathrm{Fe}$ absorption 3.41 times, from 1.59 to $5.41 \%$. Most other studies have utilized NaFeEDTA fortification (Garby \& Arrekul, 1974; Layrisse \& Martinez-Torres, 1977; Viteri et al. 1978; MacPhail et al. 1981; Ballot $e t$ al. 1989) and also found that the addition of NaFeEDTA produced a significant increase in Fe absorption in the presence of an inhibitory meal. The recent study by Ballot et al. (1989), which summarized the results of a 2-year intervention programme among the ethnic Indian population of South Africa, claimed a decrease in Fe-deficiency anaemia from 22 to $5 \%$ among females in the population when the widely used spice masala, a type of curry powder, was fortified with NaFeEDTA. Significant increases in both haemoglobin and serum ferritin levels were also observed in females. Many economically advanced countries, such as the United States, Great Britain and Sweden, also currently have wheatflour fortification programmes in operation.

The HRE method provides an especially useful assay for predicting Fe bioavailability to 
Table 4. Comparison of NaFeEDTA and ferrous sulphate $+\mathrm{Na}_{2}$ EDTA in Egyptian balady bread with $\mathrm{FeSO}_{4}$ in rats*

(Mean values with their standard errors)

\begin{tabular}{|c|c|c|c|c|c|c|c|c|}
\hline & \multicolumn{2}{|c|}{$\mathrm{FeSO}_{4}$} & \multicolumn{2}{|c|}{$\mathrm{FeSO}_{4}+\mathrm{Na}_{2} \mathrm{EDTA}$} & \multicolumn{2}{|c|}{ NaFeEDTA } & \multirow{2}{*}{$\begin{array}{c}\text { Statistical } \\
\text { significance } \\
\text { of } \\
\text { difference: } \\
P\end{array}$} & \multirow[b]{2}{*}{ LSD } \\
\hline & Mean & SE & Mean & SE & Mean & SE & & \\
\hline \multicolumn{9}{|l|}{ Body-wt (g): } \\
\hline Initial & 80 & 4 & 79 & 2 & 80 & 3 & $0 \cdot 970$ & NS \\
\hline Gain & 10 & 2 & 11 & 2 & 15 & 1 & $0 \cdot 101$ & NS \\
\hline Fe intake (mg) & $2 \cdot 67$ & $0 \cdot 15$ & $2 \cdot 56$ & $0 \cdot 12$ & $2 \cdot 61$ & $0 \cdot 10$ & 0.811 & NS \\
\hline \multicolumn{9}{|l|}{$\mathrm{Hb}(\mathrm{g} / 1):$} \\
\hline Initial & 45 & 2 & 44 & 2 & 44 & 2 & 0.987 & NS \\
\hline Gain & 54 & 5 & 87 & 3 & 87 & 3 & $<0.001$ & $1 \cdot 0$ \\
\hline \multicolumn{9}{|l|}{ PCV: } \\
\hline Initial ratio & $0 \cdot 18$ & 0.01 & $0 \cdot 18$ & 0.01 & $0 \cdot 18$ & 0.01 & 0.991 & NS \\
\hline Gain ratio & $0 \cdot 28$ & 0.01 & 0.29 & 0.01 & 0.27 & 0.01 & 0.321 & NS \\
\hline Liver wt (g) & 3.02 & $0 \cdot 14$ & 3.00 & 0.11 & $3 \cdot 14$ & $0 \cdot 13$ & 0.698 & NS \\
\hline \multicolumn{9}{|l|}{ Liver non-haem-Fe: } \\
\hline$\mu \mathrm{g} / \mathrm{g}$ & $98 \cdot 8$ & $26 \cdot 6$ & $73 \cdot 5$ & $13 \cdot 8$ & $79 \cdot 3$ & $12 \cdot 9$ & 0.614 & NS \\
\hline$\mu \mathrm{g}$ & 311 & 83 & 230 & 51 & 245 & 36 & 0.516 & NS \\
\hline \multicolumn{9}{|l|}{$\mathrm{Hb}-\mathrm{Fe}(\mathrm{mg})$} \\
\hline Initial & 0.91 & 0.09 & 0.89 & 0.06 & 0.90 & 0.06 & 0.963 & NS \\
\hline Final & $2 \cdot 21$ & 0.09 & 2.97 & $0 \cdot 12$ & $3 \cdot 12$ & $0 \cdot 12$ & $<0.001$ & 0.32 \\
\hline HRE ratio & 0.51 & 0.05 & 0.83 & 0.03 & 0.86 & 0.04 & $<0.001$ & $0 \cdot 11$ \\
\hline RBV ratiof & 1.00 & 0.09 & 1.64 & 0.06 & $1 \cdot 70$ & 0.07 & $<0.001$ & $0 \cdot 22$ \\
\hline
\end{tabular}

LSD, least significant difference; NS, not significant; Hb, haemoglobin; PCV, packed cell volume; HRE, haemoglobin regeneration efficiency; RBV, relative biological value.

* Ten animals per group were fed on the test diets containing $30 \mathrm{mg}$ fortification $\mathrm{Fe} / \mathrm{kg}$ diet during the $10 \mathrm{~d}$ repletion period; for details, see p. 589.

$\dagger$ Mean differences must equal or exceed LSD values to be statistically significant $(P<0 \cdot 05)$.

$\ddagger$ HRE of test Fe source divided by mean HRE of $\mathrm{FeSO}_{4}$.

humans when the quantity of the Fe compound or food vehicle is extremely limited, as in the present study, because of the difficulty of obtaining the large quantities of Egyptian balady bread required for the Association of Official Analytical Chemists (1984) method. HRE-derived RBV ratios obtained in the absence of ascorbic acid are consistent with those from a recent human study (Forbes et al. 1989), which found the RBV of electrolytic Fe to be 0.75 and that of $\mathrm{FePO}_{4}$ to be 0.25 . The first study found the corresponding values to be 0.75 and 0.23 . It should be noted that the rat model unsatisfactorily predicts the enhancing effect of ascorbic acid on Fe bioavailability in humans because the rat is able to synthesize ascorbic acid. Forbes et al. (1989) showed in a recent human study that the addition of $100 \mathrm{mg}$ ascorbic acid to meals fortified with $\mathrm{FeSO}_{4}, \mathrm{FePO}_{4}$ and electrolytic Fe increased bioavailability $2 \cdot 4-4$ times.

RBV ratios were generally higher in evaluating fortification compounds given with the AIN diet than with the balady bread meal because of the absence of the inhibitory phytates in the bran present in the high-extraction flour (Hallberg et al. 1987). In the present investigation, the HRE ratios obtained with the ground Egyptian balady bread were lower $(P<0.001)$ than those with the casein-based AIN 76 meal for both the $\mathrm{FeSO}_{4}$ and NaFeEDTA groups, which demonstrates the inhibitory effect of phytate in the rat model. The exception was the $\mathrm{FeSO}_{4}+\mathrm{Na}_{2}$ EDTA fortification of the casein-based AIN diet in which the HRE ratio was less than that found with the addition of $\mathrm{FeSO}_{4}$ alone, and 
significantly lower $(P<0.001)$ than that found with NaFeEDTA fortification. The reason for this is unknown, but may be due to the difference in stability of the EDTA complex in combination with the $\mathrm{Fe}$, and also to ligand interaction with the Fe compounds.

RBV ratios were significantly higher for both the $\mathrm{FeSO}_{4}+\mathrm{Na}_{2}$ EDTA- and NaFeEDTAfortified meals (1.64 and 1.70 respectively) than for the reference $\mathrm{FeSO}_{4}$, and the $\mathrm{RBV}$ ratios of the two EDTA-enhancing compounds were not significantly different when added to the Egyptian balady bread meal. Liver non-haem-Fe values were higher in the groups fed on balady bread meal than in animals that received the AIN diet, and lower body-weight gain was also observed in these groups because the protein quality of the bread was lower than that of the casein.

Because of the lower RBV ratio observed in the AIN diet fortified with $\mathrm{FeSO}_{4}+\mathrm{EDTA}$, additional human studies would be helpful to compare the enhancing potential on $\mathrm{Fe}$ absorption of the two EDTA compounds when given with inhibitory and non-inhibitory dietary components. Further studies would also be useful for examining possible mechanisms of absorption and excretion of EDTA.

The authors thank Joelle Sobotka and Pauline Bryant for technical assistance, Malcolm R. Forbes and Karl E. Davis, W. R. Grace and Co., Nashua, NH, for supplying $\mathrm{Na}_{2}$ EDTA and NaFeEDTA, and Ahmed M. Khorshid, Agricultural Research Center, Giza, Egypt, for preparing and providing Egyptian balady bread.

\section{REFERENCES}

American Institute of Nutrition (1977). Report of the Ad Hoc Committee on Standards for Nutritional Studies. Journal of Nutrition 107, 1340-1348.

American Institute of Nutrition (1980). Second report of the Ad Hoc Committee on Standards for Nutritional Studies. Journal of Nutrition 110, 1726.

Association of Official Analytical Chemists (1984). Official Methods of Analysis, 14th ed, sec 43.268. Arlington, VA: AOAC.

Ballot, D. E., MacPhail, A. P., Bothwell, T. H., Gillooly, M. \& Mayet, F. G. (1989). Fortification of curry powder with NaFe (III) EDTA in an iron-deficient population: report of a controlled iron-fortification trial. American Journal of Clinical Nutrition 49, 162-169.

Bjorn-Rasmussen, E. (1974). Iron absorption from wheat bread. Nutrition and Metabolism 16, 101-110.

Boline, D. R. \& Schrenk, W. G. (1977). Atomic absorption spectroscopy of copper and iron in plant material. Journal of Association of Official Analytical Chemists 60, 1170-1174.

Cook, J. D., Minnich, V., Moore, C. V., Rasmussen, A., Bradley, W. B. \& Finch, C. A. (1973). Absorption of fortification iron in bread. American Journal of Clinical Nutrition 26, 861-872.

Cook, J. D. \& Reusser, M. E. (1983). Iron fortification: an update. American Journal of Clinical Nutrition 38, 648-659.

Crosby, W. H. \& Munn, S. I. (1954). Standardized method for clinical hemoglobinometry. U.S. Armed Forces Medical Journal 51, 693-703.

El Guindi, M., Lynch, S. R. \& Cook, J. D. (1988). Iron absorption from fortified flat breads. British Journal of Nutrition 59, 205-213.

Forbes, A. L., Adams, C. E., Arnaud, M. J., Chichester, C. O., Cook, J. D., Harrison, B. H., Hurrell, R. F., Kahn, S. G., Morris, E. R., Tanner, J. T. \& Whittaker, P. (1989). Comparison of in vitro, animal, and clinical determinations of iron bioavailability: International Nutritional Anemia Consultative Group Task Force Report on Iron Bioavailability. American Journal of Clinical Nutrition 49, 225-238.

Garby, L. \& Arrekul, S. (1974). Iron supplementation in Thai fish-sauce. Annals of Tropical Medicine and Parasitology 68, 467-476.

Hallberg, L., Rossander, L. \& Skanberg, A. (1987). Phytates and the inhibitory effect of bran on iron absorption in man. American Journal of Clinical Nutrition 45, 988-996.

Layrisse, M. \& Martinez-Torres, C. (1977). Fe(III)EDTA complex as iron fortification. American Journal of Clinical Nutrition 30, 1166-1174.

MacPhail, A. P., Bothwell, T. H., Torrance, J. D., Derman, D. P., Bezwoda, W. R. \& Charlton, R. W. (1981). Factors affecting the absorption of iron from Fe(III)EDTA. British Journal of Nutrition 45, 215-227.

Mahoney, A. W. \& Hendricks, D. G. (1982). Efficiency of hemoglobin regeneration as a method of assessing iron bioavailability in food products. In Nutritional Bioavailability of Iron, pp. 1-11 [C. Kies, editor]. Washington DC: American Chemical Society. 
Simpson, K. M., Morris, E. R. \& Cook, J. D. (1981). The inhibitory effect of bran on iron absorption in man. American Journal of Clinical Nutrition 34, 1469-1478.

Snedecor, G. W. \& Cochran, W. G. (1967). One-way classifications. Analysis of variance. In Statistical Methods, 6th ed, pp. 258-298. Ames, Iowa: Iowa State University Press.

Tim, K. I. (1979). Orbital venous anatomy of the rat. Laboratory Animal Science 29, 636-638.

Torrance, J. D. \& Bothwell, T. H. (1968). A simple technique for measuring storage iron concentrations in formalinised liver samples. South African Journal of Medical Science 33, 9-11.

Viteri, F. E., Garcia-Ibanez, R. \& Torun, B. (1978). Sodium iron NaFeEDTA as an iron fortification compound in Central America: absorption studies. American Journal of Clinical Nutrition 31, 961-971.

Whittaker, P., Mahoney, A. W. \& Hendricks, D. G. (1984). Effect of iron-deficiency anemia on percent blood volume in growing rats. Journal of Nutrition 114, $1137-1142$.

Widdowson, E. M. \& McCance, R. A. (1942). Iron exchanges of adults on white and brown bread diets. Lancet i, 588-591. 